\title{
Gambaran Luka Korban Kecelakaan Lalu Lintas yang Dilakukan Pemeriksaan di RSUP Dr. M. Djamil Padang
}

\author{
Isnu Lucky Riandini ${ }^{1}$, Rika Susanti ${ }^{2}$, Amel Yanis $^{3}$
}

\begin{abstract}
Abstrak
Kecelakaan lalu lintas adalah suatu peristiwa dijalan yang melibatkan kendaraan atau pemakai jalan lainnya, mengakibatkan korban manusia atau kerugian harta benda. Tujuan penelitian ini adalah untuk mengetahui gambaran luka korban kecelakaan lalu lintas yang dilakukan pemeriksaan di RSUP Dr. M. Djamil Padang, mencakup jumlah kasus korban kecelakan lalu lintas berdasarkan jenis kelamin, usia, kategori pengguna jalan, jenis luka, lokasi luka dan patah tulang. Penelitian ini bersifat deskriptif retrospektif dengan cara mengumpulkan data sekunder yang diambil dari rekam medis korban kecelakaan lalu lintas (hidup dan meninggal) yang dilakukan pemeriksaan di RSUP Dr. M. Djamil Padang dari 1 Juli 2010 sampai 30 Juni 2012. Didapatkan 100 kasus kecelakaan lalu lintas (korban meninggal) dan 73 kasus (korban hidup) yang dilakukan pemeriksaan di RSUP Dr. M. Djamil Padang dengan korban terbanyak laki laki dibanding perempuan. Rentang usia terbanyak yaitu usia dewasa awal (19-35 tahun). Kategori pengguna jalan yang banyak mengalami kecelakan lalu lintas adalah pengendara roda dua. Jenis luka terbanyak yaitu luka lecet. Ada $39,2 \%$ (korban meninggal) dan 42,6\% (korban hidup). Lokasi luka terbanyak pada daerah kepala dan lokasi patah tulang terbanyak pada daerah ekstremitas bawah.
\end{abstract}

Kata kunci: kecelakaan lalu lintas, luka, VeR.

\section{Abstract}

Traffic accident is a condition involving vehicle or other street user, causing human victim or material loss. The objective of this study was to find the description of injuries to the victims of traffic accidents conducted an examination at RSUP Dr. M. Djamil Padang, Including total traffic accident victim cases which had been done a corps examination, distribution based on gender, age, street user category, type of wound, location of wound and fracture. This descriptive retrospective research conducted by taking secondary data of traffic accident victims (death and survivor) from RSUP Dr. M. Djamil Padang during period 1 July 2010 - 30 June 2012. It had been gotten 100 cases the victims of traffic accident for deaths and 73 cases for survivors at RSUP Dr. M. Djamil Padang. Male victims were larger than female victim. The largest age group were found 19-35 years old. The many street user category that experiencing traffic accidents are motor bikers. The most common wounds were found abrasion wounds which $39.2 \%$ for deaths and $42,6 \%$ for survivors. The wounds usually were found at the head areas and the fractures were found at the lower limb region.

Keywords: traffic accident, wound, VeR.

Affiliasi penulis: 1. Pendidikan Dokter FK UNAND (Fakultas Kedokteran Universitas Andalas Padang), 2. Bagian Forensik FK UNAND/RSUP Dr. M Djamil Padang, 3. Bagian Psikiatri FK Unand/RSUP Dr. M Djamil Padang

Korespondensi:Isnu Lucky Riandini, E-mail : Isnu_lucky@yahoo.com, Telp: 085355678350

\section{PENDAHULUAN}

Jalan raya yang awalnya berfungsi memperlancar pergerakan manusia dan barang dari suatu tempat ke tempat lain, sekarang sudah menjadi sumber terjadinya kecelakaan Ialu lintas. ${ }^{1}$ Pada tahun 
2009 jumlah kendaraan yang terlibat kecelakaan lalu lintas di Indonesia mengalami peningkatan $57,76 \%{ }^{2}$

Data statistik WHO menunjukkan bahwa kecelakaan lalu lintas pada tahun 1998 menduduki peringkat ke-9 sebagai penyebab kematian di dunia. Diperkirakan pada tahun 2020, kecelakaan lalu lintas akan menjadi penyebab kematian ke-3 tertinggi di dunia di bawah penyakit jantung koroner dan depresi berat. $^{3}$

Jumlah korban yang mengalami kecelakaan lalu lintas di Indonesia terus mengalami peningkatan sampai dengan tahun 2009, baik luka ringan maupun luka berat. Korban kecelakaan lalu lintas di Indonesia pada tahun 2009 berjumlah 106.384 dan ini merupakan jumlah korban kecelakaan lalu lintas tertinggi selama 5 tahun terakhir. ${ }^{3}$ Berdasarkan data dari Direktorat Jendral Perhubungan Darat dalam Qoriyah, pada tahun 2010 tercatat 109.319 kasus kecelakaan lalu lintas dengan korban meninggal dunia 31.234 orang, luka berat 46.851 orang, dan luka ringan 97.702 orang, sedangkan pada tahun 2011, tercatat 109.776 kasus dengan korban meninggal dunia 31.185 orang, luka berat 36.767 orang, dan luka ringan 108.811 orang. Data dari Markas Besar Polisi Republik Indonesia mulai dari Januari hingga pertengahan Februari 2012, terjadi 9.884 kasus kecelakaan lalu lintas, dengan korban meninggal dunia 1.547 orang, luka berat 2.562 orang, dan luka ringan 7.564 orang. $^{4}$

Berdasarkan Data Direktorat Lalu Lintas Polda Sumatera Barat, jumlah kecelakaan lalu lintas di kota Padang pada tahun 2011 mencapai 551 kasus, dengan korban jiwa 67 orang, luka berat 401 orang, dan luka ringan 397 orang. Terjadi sedikit penurunan pada tahun 2012, jumlah kecelakaan lalu lintas di kota Padang mencapai 540 kasus, dengan korban jiwa 80 orang, luka berat 318 orang dan luka ringan 447 orang. Dimana dari seluruh kejadian di kota Padang yang sering terjadi kecelakaan adalah jalan Bypass, jalan Raya Indarung, jalan Adinegoro, jalan Dr. Soetomo dan jalan Lubuk Begalung.

Pada penelitian yang dilakukan terhadap korban kecelakaan lalu lintas di Bagian Forensik RSUP Dr. M. Djamil Padang tahun 1998-2000. Terdapat 164 kasus kecelakaan lalu lintas dimana didapatkan 93,29\% kasus dengan cedera kepala.
Luka terbanyak adalah luka lecet yaitu 39,62\%, lokasi luka terbanyak di regio frontalis et orbitalis, patah tulang terbanyak adalah os. frontal sebanyak $19,40 \%$, umur terbanyak mengalami cedera kepala yaitu antara 11-30 tahun sebanyak 48,27\%, 67,27\% korban adalah laki-laki dan yang paling besar menelan korban adalah sepeda motor dimana cedera kepala sebagai penyebab utama kematiannya. ${ }^{5}$

Hasil survey di kota Semarang menunjukkan bahwa korban kecelakaan lalu lintas terbesar adalah kelompok usia 15-21 tahun yaitu $38,18 \%$ dan peringkat kedua usia 21-30 tahun. ${ }^{6}$ Data Riset Kesehatan Dasar tahun 2007 dalam Riyadina menunjukkan cedera akibat kecelakaan lalu lintas lebih tinggi pada laki-laki yaitu 31,9\% dibandingkan perempuan $19,8 \%$ dan kelompok umur terbanyak mengalami kecelakaan lalu lintas ialah usia 15-59 tahun sebesar $38,8 \%{ }^{7}$

Lebih dari $80 \%$ pasien yang masuk ke ruang gawat darurat adalah disebabkan oleh kecelakaan lalu lintas, berupa tabrakan sepeda motor, mobil, sepeda dan penyeberang jalan yang ditabrak. ${ }^{8}$ Hasil penelitian Lulie dan Hatmoko tahun 2006 di Yogyakarta mendapatkan dari 178 responden yang menggunakan sepeda motor, 112 responden (82,58\%) pernah mendapat kecelakaan lalu lintas. Responden yang mengalami luka berat sebanyak 24 orang, luka ringan 122 orang. Bagian luka yang dialami responden tesebar ada di kepala, badan, tangan, dan kaki. ${ }^{1}$

Mengingat pentingnya masalah ini dan belum adanya data lengkap mengenai gambaran luka pada kecelakaan lalu lintas di RSUP Dr. M. Djamil Padang, perlu dilakukan penelitian mengenai gambaran luka pada korban kecelakaan lalu lintas yang dilakukan pemeriksaan di RSUP Dr. M. Djamil Padang periode 1 Juli 2010 - 30 Juni 2012.

\section{METODE}

Penelitian ini dilakukan di Bagian Forensik RSUP Dr. M. Djamil Padang pada bulan Oktober Desember 2012. Sampel penelitian ini adalah data korban kasus kecelakaan lalu lintas baik yang hidup maupun meninggal yang dilakukan pemeriksaan di RSUP Dr. M. Djamil Padang mulai 1 Juli 2010 sampai 30 Juni 2012. Sampel sesuai dengan kriteria inklusi yaitu: data pemeriksaan yang lengkap yang dibuatkan 
VeRnya dan telah ditandatangani oleh dokter yang melakukan pemeriksaan. Populasi dari penelitian ini adalah semua kasus kecelakaan lalu lintas yang masuk ke RSUP Dr. M. Djamil Padang yang dimintakan pemeriksaan. Semua data sekunder kecelakaan lalu-lintas yang dibuatkan hasil pemeriksaan diambil datanya, kemudian diolah secara manual berdasarkan kelompok: Jenis kelamin, umur, kategori pengguna jalan, jenis luka, lokasi luka dan lokasi patah tulang.

\section{HASIL}

Pada penelitian ini diperoleh data kasus kecelakaan lalu lintas selama 2 tahun (1 Juli 2010 - 30 Juni 2012) yang dilakukan pemeriksaan di RSUP Dr. M. Djamil Padang sebanyak 173 kasus.

Tabel 1. Korban meninggal kasus kecelakaan lalu lintas yang dilakukan pemeriksaan di RSUP Dr. M. Djamil Padang periode 1 Juli 2010 - 30 Juni 2012

\begin{tabular}{llc}
\hline $\begin{array}{l}\text { Kecelakaan Lalu } \\
\text { Lintas }\end{array}$ & n \\
\hline $\begin{array}{l}\text { 1 Juli } 2010-30 \text { Juni } \\
2011\end{array}$ & 58 kasus \\
1 Juli $2011-30$ Juni & 42 kasus \\
2012 & \\
\hline Jumlah & 100 \\
\hline Keterangan : & \\
$\mathrm{n}=$ Jumlah kasus & \\
$\%=$ Persentase kasus &
\end{tabular}

Tabel 1 menggambarkan distribusi terbanyak kasus kecelakaan lalu lintas korban meninggal yang dilakukan pemeriksaan yaitu pada 1 Juli 2010 - 30 Juli 2011 terdapat 58 kasus (58\%).

Tabel 2. Korban hidup kasus kecelakaan lalu lintas yang dilakukan pemeriksaan di RSUP Dr. M. Djamil Padang periode 1 Juli 2010 - 30 Juni 2012

\begin{tabular}{lcc}
\hline Kecelakaan Lalu Lintas & & \\
& & \\
\hline 1 Juli $2010-30$ Juni 2011 & 39 kasus & 53,4 \\
1 Juli $2011-30$ Juni 2012 & 34 kasus & 46,6 \\
\hline Jumlah & 73 kasus & 100 \\
\hline
\end{tabular}

Distribusi terbanyak kasus kecelakaan lalu lintas korban hidup (Tabel 2) yang dilakukan pemeriksaan yaitu pada 1 Juli 2010 - 30 Juni 2011 terdapat 39 kasus $(53,4 \%)$.

Tabel 3. Distribusi jenis kelamin pada korban meninggal akibat kecelakaan lalu lintas yang dilakukan pemeriksaan di RSUP Dr. M. Djamil Padang periode 1 Juli 2010 - 30 Juni 2012

\section{Juli 2010 - 1 Juli 2011 - \\ 30 Juni 201130 Juni 2012}

\begin{tabular}{lllll}
\multicolumn{1}{c}{ Jenis Kelamin } & \multicolumn{4}{c}{} \\
\cline { 2 - 5 } & $\mathrm{n}$ & $\%$ & $\mathrm{n}$ & $\%$ \\
\hline Laki - Laki & 35 & 60 & 32 & 76 \\
Perempuan & 23 & 40 & 10 & 24 \\
\hline Jumlah & 58 & 100 & 42 & 100 \\
\hline
\end{tabular}

Dari Tabel 3 di atas dapat dilihat bahwa distribusi terbanyak adalah pada jenis kelamin lakilaki yaitu dengan perbandingan laki-laki dengan perempuan 1,5: 1 pada 1 Juli 2010 - 30 Juni 2011 dan 3,2 : 1 pada 1 Juli 2011- 30 Juni 2012

Tabel 4. Distribusi jenis kelamin pada korban hidup akibat kecelakaan lalu lintas yang dilakukan pemeriksaan di RSUP Dr. M. Djamil Padang periode 1 Juli 2010 - 30 Juni 2012

\begin{tabular}{|c|c|c|c|c|}
\hline \multirow{2}{*}{ Jenis ke } & \multicolumn{2}{|c|}{$\begin{array}{l}1 \text { Juli } 2010- \\
30 \text { Juni } 2011\end{array}$} & \multicolumn{2}{|c|}{$\begin{array}{l}1 \text { Juli } 2011- \\
30 \text { Juni } 2012\end{array}$} \\
\hline & $\mathrm{n}$ & $\%$ & $\mathrm{n}$ & $\%$ \\
\hline Laki-Laki & 28 & 72 & 21 & 62 \\
\hline Perempuan & 11 & 28 & 13 & 38 \\
\hline Jumlah & 39 & 100 & 34 & 100 \\
\hline
\end{tabular}

Tabel 4 memperlihatkan distribusi terbanyak adalah pada jenis kelamin laki - laki yaitu dengan perbandingan laki - laki dengan perempuan $2,5: 1$ pada 1 Juli 2010 - 30 Juni 2011 dan 1,6 : 1 pada 1 Juli 2011- 30 Juni 2012.

Hasil penelitian ini sesuai dengan penelitian yang dilakukan oleh Riyadina et al tahun 2009 yang menyatakan bahwa distribusi korban kecelakaan lalu lintas lebih didominasi kaum laki-laki, hal ini disebabkan karena laki-laki mayoritas lebih banyak 
beraktivitas di luar rumah untuk bekerja sehingga mempunyai resiko lebih tinggi mengalami cedera

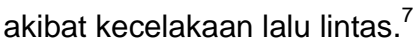

Tabel 5. Distribusi umur pada korban meninggal akibat kecelakaan lalu lintas yang dilakukan pemeriksaan di RSUP Dr. M. Djamil Padang periode 1 Juli 2010 - 30 Juni 2012

\begin{tabular}{ccccc}
\hline $\begin{array}{c}\text { Umur } \\
\text { (tahun) }\end{array}$ & \multicolumn{2}{c}{$\begin{array}{c}\text { 1 Juli 2010 - } \\
\text { 30 Juni 2011 }\end{array}$} & \multicolumn{2}{c}{ 1 Juli 2011 - } \\
& 30 Juni 2012 & \\
\cline { 2 - 5 } & $\mathbf{n}$ & $\%$ & $\mathbf{n}$ & $\%$ \\
\hline$<5$ & 1 & 1,7 & 0 & 0 \\
$6-11$ & 1 & 1,7 & 3 & 7,1 \\
$12-18$ & 12 & 20,7 & 11 & 26,3 \\
$19-35$ & 17 & 29,3 & 14 & 33,3 \\
$36-60$ & 14 & 24,1 & 8 & 19 \\
$>60$ & 13 & 22,65 & 6 & 14,3 \\
\hline
\end{tabular}

Distribusi umur terbanyak (Tabel 5), pada korban meninggal adalah adalah rentang usia $19-35$ tahun (masa dewasa awal) terlihat pada 1 Juli 2010 30 Juni 2011 terdapat 17 kasus (29,35\%) dan 1 Juli 2011 - 30 Juni 2012 terdapat 14 kasus (33,3\%).

Tabel 6: Distribusi umur pada korban hidup akibat kecelakaan lalu lintas yang dilakukan pemeriksaan di RSUP Dr. M. Djamil Padang periode 1 Juli 2010 - 30 Juni 2012

\begin{tabular}{|c|c|c|c|c|}
\hline \multirow{2}{*}{$\begin{array}{l}\text { Umur } \\
\text { (tahun) }\end{array}$} & \multicolumn{2}{|c|}{$\begin{array}{l}1 \text { Juli } 2010- \\
30 \text { Juni } 2011\end{array}$} & \multicolumn{2}{|c|}{$\begin{array}{l}1 \text { Juli } 2011 \text { - } \\
30 \text { Juni } 2012\end{array}$} \\
\hline & $\mathbf{n}$ & $\%$ & $\mathbf{n}$ & $\%$ \\
\hline$<5$ & 0 & 0 & 2 & 5,8 \\
\hline $6-11$ & 2 & 5,1 & 1 & 2,9 \\
\hline $12-18$ & 8 & 20,5 & 5 & 14,6 \\
\hline $19-35$ & 12 & 30,7 & 11 & 32,6 \\
\hline $36-60$ & 9 & 23,2 & 7 & 20,6 \\
\hline$>60$ & 8 & 20,5 & 8 & 13,5 \\
\hline
\end{tabular}

Distribusi umur terbanyak pada korban hidup (Tabel 6), adalah rentang usia 19 - 35 tahun (masa dewasa awal) terlihat pada 1 Juli 2010 - 30 Juni 2011 terdapat 12 kasus $(30,7 \%)$ dan 1 Juli 2011 - 30 Juni 2012 terdapat 11 kasus $(32,6 \%)$.

Sesuai dengan analisis data yang dilakukan oleh Direktorat Jenderal Perhubungan Darat menunjukkan bahwa pengemudi berusia 16-30 tahun adalah penyebab terbesar kecelakaan lalu lintas jalan $(55,99 \%) .{ }^{9}$ Usia dewasa awal merupakan kelompok usia yang produktif dimana mempunyai mobilitas yang lebih tinggi dibandingkan dengan kelompok umur lain ${ }^{7}$

Tabel 7: Distribusi kategori pengguna jalan pada korban meninggal akibat kecelakaan lalu lintas yang dilakukan pemeriksaan di RSUP Dr. M. Djamil Padang periode 1 Juli 2010 - 30 Juni 2012

\begin{tabular}{lcccc}
\hline $\begin{array}{l}\text { Kategori pengguna } \\
\text { Jalan }\end{array}$ & \multicolumn{2}{c}{ 1 Juli 2010 - } & \multicolumn{2}{c}{ 1 Juli 2011 - } \\
& 30 Juni 2011 & \multicolumn{2}{c}{ 30 Juni 2012} \\
\hline Pejalan kaki & $\mathbf{n}$ & $\%$ & $\mathbf{n}$ & $\%$ \\
$\begin{array}{l}\text { Pengendara } \\
\text { sepeda motor }\end{array}$ & 23 & 56,1 & 17 & 58,6 \\
$\begin{array}{l}\text { Pengedara mobil } \\
\text { Jumlah }\end{array}$ & 11 & 26,8 & 9 & 31 \\
\hline
\end{tabular}

Distribusi kategori pengguna jalan (Tabel 7), korban meninggal terbanyak adalah pengendara sepeda motor yaitu pada 1 Juli 2010 - 30 Juni 2011 terdapat 23 kasus (56,1\%) dan 1 Juli 2011 - 30 Juni 2012 terdapat 17 kasus $(58,6 \%)$.

Tabel 8: Distribusi kategori pengguna jalan pada korban hidup akibat kecelakaan lalu lintas yang dilakukan pemeriksaan di RSUP Dr. M. Djamil Padang periode 1 Juli 2010 - 30 Juni 2012

\begin{tabular}{|c|c|c|c|c|}
\hline \multirow{2}{*}{$\begin{array}{c}\text { Kategori pengguna } \\
\text { Jalan }\end{array}$} & \multicolumn{2}{|c|}{$\begin{array}{l}1 \text { Juli } 2010 \text { - } \\
30 \text { Juni } 2011\end{array}$} & \multicolumn{2}{|c|}{$\begin{array}{l}1 \text { Juli } 2011 \text { - } \\
30 \text { Juni } 2012\end{array}$} \\
\hline & $\mathbf{n}$ & $\%$ & $\mathbf{n}$ & $\%$ \\
\hline Pejalan kaki & 5 & 20,8 & 6 & 22,2 \\
\hline $\begin{array}{l}\text { Pengendara sepeda } \\
\text { motor }\end{array}$ & 12 & 50 & 14 & 51,9 \\
\hline Pengedara mobil & 7 & 29,2 & 7 & 25,9 \\
\hline Jumlah & 24 & 100 & 27 & 100 \\
\hline
\end{tabular}

Distribusi kategori pengguna jalan (Tabel 8), korban hidup terbanyak adalah pengendara sepeda motor yaitu pada 1 Juli 2010 - 30 Juni 2011 terdapat 12 kasus (50\%) dan 1 Juli 2011 - 30 Juni 2012 terdapat 14 kasus $(51,9 \%)$.

Data statistik kecelakaan di Yogyakarta tahun 2004, menginformasikan kecelakaan di jalan raya yang terbanyak adalah sepeda motor sebanyak $41 \%$, hal ini terjadi akibat jumlah kendaraan bermotor yang meningkat tiap tahunnya. ${ }^{3}$ Satlantas Polres Karanganyar (2011) mengatakan pengendara sepeda 
motor yang mengalami kecelakaan didapati $15 \%$ mengkonsumsi alkohol. Alkohol dalam tubuh akan menyebabkan penekanan pada sistem saraf sehingga dapat mempengaruhi pusat pengendalian diri serta perubahan dalam menilai sesuatu atau dapat mengakibatkan

ketidakmampuan

untuk mengkoordinasi visual scanning dan kemampuan psikomotor, hal ini dapat menjadi faktor resiko terjadinya kecelakaan lalu lintas. ${ }^{10}$

Tabel 9. Distribusi jenis luka dan lokasi luka pada korban meninggal kecelakaan lalu lintas yang dilakukan pemeriksan di RSUP Dr. M. Djamil Padang periode 1 Juli 2010 - 30 Juni 2011

\begin{tabular}{|c|c|c|c|c|c|c|c|c|c|c|c|c|c|c|c|c|}
\hline \multirow{2}{*}{ Jenis Luka } & \multicolumn{2}{|c|}{ Kepala } & \multicolumn{2}{|c|}{ Leher } & \multicolumn{2}{|c|}{ Dada } & \multirow{2}{*}{$\begin{array}{l}\text { Perut } \\
\mathbf{n}\end{array}$} & \multicolumn{3}{|c|}{ Punggung } & \multicolumn{2}{|c|}{ E.atas } & \multicolumn{2}{|c|}{ E.bawah } & \multicolumn{2}{|c|}{ Jumlah } \\
\hline & $\mathbf{n}$ & $\%$ & $\mathbf{n}$ & $\%$ & $\mathbf{n}$ & $\%$ & & $\%$ & $\mathbf{n}$ & $\%$ & $\mathbf{n}$ & $\%$ & $n$ & $\%$ & $n$ & $\%$ \\
\hline Luka Memar & 28 & 44 & 1 & 25 & 4 & 29 & 0 & 0 & 3 & 33,3 & 5 & 26,3 & 7 & 29,2 & 48 & 34,8 \\
\hline Luka Lecet & 19 & 30 & 2 & 50 & 5 & 35,5 & 2 & 50 & 4 & 44,4 & 11 & 57,9 & 11 & 45,8 & 54 & 39,2 \\
\hline Luka Robek & 17 & 26 & 1 & 25 & 5 & 35,5 & 2 & 50 & 2 & 22,3 & 3 & 15,8 & 6 & 25 & 36 & 26 \\
\hline Jumlah & 64 & 100 & 4 & 100 & 14 & 100 & 4 & 100 & 9 & 100 & 19 & 100 & 24 & 100 & 138 & 100 \\
\hline Persentase & & 46,4 & & 2,9 & & 10,1 & & 2,9 & & 6,5 & & 13,8 & & 17,4 & & 100 \\
\hline
\end{tabular}

Distribusi jenis luka dan lokasi luka pada Tabel 9 diatas terlihat pada korban meninggal kecelakaan lalu lintas 1 Juli 2010 - 30 Juni 2011 didapatkan jenis luka terbanyak yaitu luka lecet sebanyak 54 buah $(39,2 \%)$. Lokasi luka terbanyak pada tubuh yaitu di kepala sebanyak 64 buah $(46,4 \%)$.

Tabel 10. Distribusi jenis luka dan lokasi luka pada korban hidup kecelakaan lalu lintas yang dilakukan pemeriksaan di RSUP Dr. M. Djamil Padang periode 1 Juli 2010 - 30 Juni 2011

\begin{tabular}{|c|c|c|c|c|c|c|c|c|c|c|c|c|c|c|c|c|}
\hline \multirow[t]{2}{*}{ Jenis Luka } & \multicolumn{2}{|c|}{ Kepala } & \multicolumn{2}{|c|}{ Leher } & \multicolumn{2}{|c|}{ Dada } & \multicolumn{2}{|c|}{ Perut } & \multicolumn{3}{|c|}{ Punggung } & \multicolumn{3}{|c|}{$\begin{array}{c}\text { Ekstremitas } \\
\text { atas }\end{array}$} & \multicolumn{2}{|c|}{$\begin{array}{c}\text { Ekstremitas } \\
\text { bawah }\end{array}$} \\
\hline & $\mathbf{n}$ & $\%$ & $\mathrm{n}$ & $\%$ & $n$ & $\%$ & $\mathrm{n}$ & $\%$ & $\mathrm{n}$ & $\%$ & $\mathrm{n}$ & $\%$ & $\mathbf{n}$ & $\%$ & $\mathbf{n}$ & $\%$ \\
\hline Memar & 12 & 48 & 0 & 0 & 1 & 33,3 & 0 & 0 & 0 & 0 & 1 & 14,3 & 4 & 31 & 18 & 36,7 \\
\hline Lecet & 7 & 28 & 0 & 0 & 2 & 66,7 & 0 & 0 & 0 & 0 & 6 & 85,7 & 6 & 46 & 21 & 42,6 \\
\hline Robek & 6 & 24 & 0 & 0 & 0 & 0 & 1 & 100 & 0 & 0 & 0 & 0 & 3 & 23 & 10 & 20,7 \\
\hline Jumlah & 25 & 100 & 0 & 100 & 3 & 100 & 1 & 100 & 0 & 100 & 7 & 100 & 13 & 100 & 49 & 100 \\
\hline Persentase & & 51 & & 0 & & 6 & & 2 & & 0 & & 14,5 & & 26,5 & & 100 \\
\hline
\end{tabular}

Dari Tabel 10 diatas terlihat pada korban hidup kecelakaan lalu lintas 1 Juli 2010 - 30 Juni 2011 didapatkan jenis luka terbanyak adalah luka lecet sebanyak 21 buah (42,6\%). Lokasi luka terbanyak pada tubuh yaitu di kepala sebanyak 25 buah (51\%).

Tabel 11. Distribusi jenis luka dan lokasi luka pada korban meninggal kecelakaan lalu lintas yang dilakukan pemeriksaan di RSUP Dr. M. Djamil Padang periode 1 Juli 2011 - 30 Juni 2012

\begin{tabular}{|c|c|c|c|c|c|c|c|c|c|c|c|c|c|c|c|c|}
\hline \multirow{2}{*}{$\begin{array}{l}\text { Jenis } \\
\text { Luka }\end{array}$} & \multicolumn{2}{|c|}{ Kepala } & \multicolumn{2}{|c|}{ Leher } & \multicolumn{2}{|c|}{ Dada } & \multicolumn{2}{|c|}{ Perut } & \multicolumn{2}{|c|}{ Punggung } & \multicolumn{2}{|c|}{$\begin{array}{c}\text { Ekstremitas } \\
\text { atas }\end{array}$} & \multicolumn{2}{|c|}{$\begin{array}{l}\text { Ekstrremitas } \\
\text { bawah }\end{array}$} & \multicolumn{2}{|c|}{ Jumlah } \\
\hline & $\mathrm{n}$ & $\%$ & $\mathrm{n}$ & $\%$ & $n$ & $\%$ & $\mathrm{n}$ & $\%$ & $\mathbf{n}$ & $\%$ & $\mathbf{n}$ & $\%$ & $\mathbf{n}$ & $\%$ & $\mathbf{n}$ & $\%$ \\
\hline Memar & 19 & 36 & 0 & 0 & 4 & 33,3 & 1 & 16,7 & 1 & 11,1 & 5 & 21,8 & 10 & 32,2 & 40 & 28,3 \\
\hline Lecet & 17 & 32 & 4 & 57,1 & 6 & 50 & 3 & 50 & 7 & 77,8 & 14 & 60,8 & 12 & 38,7 & 63 & 44,8 \\
\hline Robek & 17 & 32 & 3 & 42,9 & 2 & 16,7 & 2 & 33,3 & 1 & 11,1 & 4 & 17,4 & 9 & 29,1 & 38 & 26,9 \\
\hline Jumlah & 53 & 100 & 7 & 100 & 12 & 100 & 6 & 100 & 9 & 100 & 23 & 100 & 31 & 100 & 141 & 100 \\
\hline Persentase & & 37,6 & & 5 & & 8,5 & & 4,2 & & 6,4 & & 16,3 & & 22 & & 100 \\
\hline
\end{tabular}


Tabel 11 menggambarkan korban meninggal kecelakaan lalu lintas 1 Juli 2011 - 30 Juni 2012 didapatkan jenis luka terbanyak yaitu luka lecet sebanyak 63 buah (44,8\%). Lokasi luka terbanyak pada tubuh yaitu di kepala sebanyak 53 buah $(37,6 \%)$.

Tabel 12. Distribusi jenis luka dan lokasi luka pada korban hidup kecelakaan lalu lintas yang dilakukan pemeriksaan di RSUP Dr. M. Djamil Padang periode 1 Juli 2011 - 30 Juni 2012

\begin{tabular}{|c|c|c|c|c|c|c|c|c|c|c|c|c|c|c|c|c|}
\hline \multirow[t]{2}{*}{ Jenis Luka } & \multicolumn{2}{|c|}{ Kepala } & \multicolumn{2}{|c|}{ Leher } & \multicolumn{2}{|c|}{ Dada } & \multicolumn{2}{|c|}{ Perut } & \multicolumn{2}{|c|}{ Punggung } & \multicolumn{2}{|c|}{$\begin{array}{c}\text { Ekstremitas } \\
\text { atas }\end{array}$} & \multicolumn{2}{|c|}{$\begin{array}{c}\text { Ekstremitas } \\
\text { bawah }\end{array}$} & \multicolumn{2}{|c|}{ Jumlah } \\
\hline & $\mathbf{n}$ & $\%$ & $\mathbf{n}$ & $\%$ & $\mathbf{n}$ & $\%$ & $\mathbf{n}$ & $\%$ & $\mathrm{n}$ & $\%$ & $\mathrm{n}$ & $\%$ & $\mathrm{n}$ & $\%$ & $\mathrm{n}$ & $\%$ \\
\hline Memar & 10 & 34,5 & 0 & 0 & 0 & 0 & 0 & 0 & 0 & 0 & 4 & 66,7 & 0 & 0 & 14 & 29,2 \\
\hline Lecet & 10 & 34,4 & 0 & 0 & 1 & 33,3 & 1 & 100 & 1 & 50 & 1 & 16,7 & 4 & 66,7 & 18 & 37,5 \\
\hline Robek & 9 & 31 & 1 & 100 & 2 & 66,7 & 0 & 0 & 1 & 50 & 1 & 16,7 & 2 & 33,3 & 16 & 33,3 \\
\hline Jumlah & 29 & 100 & 1 & 100 & 3 & 100 & 1 & 100 & 2 & 100 & 6 & 100 & 6 & 100 & 48 & 100 \\
\hline Persentase & & 60,4 & & 2,1 & & 6,25 & & 2,1 & & 4,2 & & 12,5 & & 12,5 & & 100 \\
\hline
\end{tabular}

Distribusi jenis luka dan lokasi luka pada Tabel 12 diatas terlihat pada korban hidup kecelakaan lalu lintas 1 Juli 2011 - 30 Juni 2012 didapatkan jenis luka terbanyak yaitu luka lecet sebanyak 18 buah (37,5\%). Lokasi luka terbanyak pada tubuh yaitu di kepala sebanyak 29 buah $(60,4 \%)$.

Penelitian Riyadina tahun 2009 mendapatkan proporsi jenis cedera terbanyak akibat kecelakaan lalu lintas di Indonesia adalah luka lecet sebanyak 65,9\%. ${ }^{7}$ Hal ini juga seperti yang ditulis Lulie tahun 2006 bahwa pada kecelakaan lalu lintas sepeda motor sering terjadi luka lecet karena ketika terjatuh biasanya pengendara motor akan terseret akibat gaya tolak, gesekan antara aspal, baju dan kulit akan menghasilkan luka lecet pada bagian yang berkontak langsung. ${ }^{1}$

Penelitian Wahyudi tahun 2012 mendapatkan cedera kepala merupakan urutan pertama dari semua jenis cedera yang dialami korban kecelakaan lalu lintas. Cedera kepala merupakan cedera tersering pada kecelakaan lalu lintas. ${ }^{10}$ Pada kecelakaan sepeda motor, cedera kepala sering terjadi akibat kelalaian pengendara sendiri yang sering tidak menggunakan pengaman atau jika menggunakan tapi tidak benar yaitu helm yang tidak standar atau pengikat yang tidak terpasang. ${ }^{1}$

Distribusi lokasi patah tulang pada Tabel 13 terlihat pada korban meninggal kecelakaan lalu lintas pada 1 Juli 2010 - 30 Juni 2011 didapatkan lokasi patah tulang terbanyak pada tubuh korban yaitu patah tulang ekstremitas bawah 21 buah (38,8\%). Pada 1 Juli 2011 - 30 Juni 2012 didapatkan lokasi patah tulang terbanyak pada tubuh korban yaitu patah tulang ekstremitas bawah 15 buah (34,2\%).

Tabel 13. Distribusi lokasi patah tulang pada korban meninggal kecelakaan lalu lintas yang dilakukan pemeriksaan di RSUP Dr. M. Djamil Padang periode 1 Juli 2010 - 30 Juni 2012

\begin{tabular}{lcccc}
\hline Lokasi Patah & \multicolumn{2}{c}{$\mathbf{1}$ Juli 2010 - } & \multicolumn{2}{c}{ 1 Juli 2011 - } \\
tulang & $\mathbf{3 0 ~ J u n i ~ 2 0 1 1}$ & 30 Juni 2012 \\
\cline { 2 - 5 } & $\mathbf{n}$ & $\%$ & $\mathbf{n}$ & $\%$ \\
\hline Kepala & 19 & 35,1 & 9 & 20,4 \\
Leher & 0 & 0 & 1 & 2,3 \\
Dada & 3 & 5,6 & 6 & 13,6 \\
Punggung & 0 & 0 & 1 & 2,3 \\
E. Atas & 11 & 20,5 & 12 & 27,2 \\
E.Bawah & 21 & 38,8 & 15 & 34,2 \\
\hline Jumlah & 54 & 100 & 44 & 100 \\
\hline
\end{tabular}

Tabel 14 dibawah ini terlihat pada korban hidup kecelakaan lalu lintas pada 1 Juli 2010 - 30 Juni 2011 didapatkan lokasi patah tulang terbanyak pada tubuh korban yaitu patah tulang ekstremitas bawah 20 buah (60,6\%). Pada 1 Juli 2011 - 30 Juni 2012 didapatkan lokasi patah tulang terbanyak pada tubuh korban yaitu patah tulang ekstremitas bawah 12 buah (44,4\%). Patah tulang ekstremitas bawah pada kecelakaan roda empat biasanya terjadi akibat kaki membentur benda yang ada didepannya saat terjadi hentakan 
akibat penghentian mobil secara tiba-tiba, contohnya dashboard atau kursi depan. Sedangkan patah tulang ekstremitas pada kecelakan roda dua biasanya terjadi akibat tumbukan primer oleh kendaraan lain, atau terbentur struktur jalanan yang keras. ${ }^{12}$

Tabel 14. Distribusi lokasi patah tulang pada korban hidup kecelakaan lalu lintas yang dilakukan pemeriksaan di RSUP Dr. M. Djamil Padang periode 1 Juli 2010 - 30 Juni 2012

\begin{tabular}{lcccc}
\hline $\begin{array}{l}\text { Lokasi Patah } \\
\text { tulang }\end{array}$ & $\begin{array}{l}\text { 1 Juli 2010 - } \\
\text { 30 Juni 2011 }\end{array}$ & $\begin{array}{c}\text { 1 Juli 2011 - } \\
\text { 30 Juni 2012 }\end{array}$ \\
\hline & $\mathbf{n}$ & $\%$ & $\mathbf{n}$ & $\%$ \\
\hline Kepala & 5 & 15,2 & 6 & 22,2 \\
Leher & 0 & 0 & 0 & 0 \\
Dada & 1 & 3 & 2 & 7,4 \\
Punggung & 0 & 0 & 0 & 0 \\
E. Atas & 7 & 21,2 & 7 & 26 \\
E.Bawah & 20 & 60,6 & 12 & 44,4 \\
\hline Jumlah & 33 & 100 & 27 & 100 \\
\hline
\end{tabular}

\section{KESIMPULAN}

Selama 2 tahun (1 Juli 2010 - 30 Juni 2012) terdapat 173 kasus kecelakaan lalu lintas yang dilakukan pemeriksaan di RSUP Dr. M. Djamil Padang. Terdiri atas 100 korban meninggal dan 73 korban hidup. Jenis kelamin laki-laki merupakan korban terbanyak, baik pada korban meninggal maupun korban hidup. Umur terbanyak yang mengalami kecelakaan lalu lintas adalah kelompok umur dewasa awal (19 - 35 tahun). Pengendara sepeda motor merupakan penyumbang tebanyak korban kecelakaan lalu lintas. Dilihat dari jenis luka, pada hasil penelitian ini didapatkan luka terbanyak adalah luka lecet dengan lokasi tersering di daerah kepala, sedangkan lokasi patah tulang terbanyak terdapat pada daerah ekstremitas bawah.

\section{DAFTAR PUSTAKA}

1. Lulie $Y$, Hatmoko JT. Analisis hubungan kecepatan dengan tebal helm yang direkomendasikan. Jurnal Teknik Sipil. 2006; 6(2):171-84.

2. Kementrian Perhubungan. Statistik perhubungan. Jakarta: Dinas Perhubungan; 2010.

3. Savitri WP, Indawati $R$. Estimasi resiko pada lanjut usia yang mengalami kecelakaan lalu lintas di kota Surabaya. Jurnal UNAIR. 2012; 52-61.

4. Qoriyah NM. Perbedaan kelelahan mata yang terpapar silau dalam mengemudi angkot pada siang hari dan malam haritrayek JoharBanyumanik. Jurnal Kesehatan Masyarakat. 2012; 1(2):777-84.

5. Rahmi W. Gambaran cedera kepala korban kecelakaan yang dilakukan pemeriksaan luar jenazah di bagian Forensik RSUP Dr. M. Djamil Padang periode 1 Januari 1997 - 31 Desember 2000. Padang: Fakultas Kedokteran Universitas Andalas Padang. 2002.

6. Samekto AA. Studi tentang karakteristik korban kecelakaan lalu lintas di kota Semarang. Jurnal Sains dan Teknik Maritim. 2009;7(2):78-86.

7. Riyadina W, Suhardi, Permana M. Pola dan determinan sosiodemografi cedera akibat kecelakaan Ialu lintas di Indonesia. Majalah Kedokteran Indonesia. 2009; 59(10): 464-72.

8. Japardi I. Patologi dan fisiologi cedera kepala. Jakarta: Bhuana Ilmu Populer; 2009.

9. Warpani SP. Pengelolaan lalu lintas dan angkutan jalan. Bandung: ITB; 2002.

10. Wahyudi S. Faktor resiko yang berhubungan dengan tingkat keparahan cedera kepala. Unnes Jurnal of Public Health. 2012;2(1):41-8.

11. Gruendemann BJ, Fernsebner B. Buku ajar keperawatan perioperatif. Jakarta: EGC; 2005.

12. Tarwoto. Keperawatan medical bedah. Jakarta: Sagung Seto; 2007. 